\title{
An Overview of American Interstate Ecological Governance and the Enlightenment for China
}

\author{
Guo Yongyuan, Xiao Li \\ School of Public Administration, Shanxi University of Finance and Economics, Taiyuan, China \\ Email address: \\ 675064952@qq.com (Guo Yongyuan)
}

To cite this article:

Guo Yongyuan, Xiao Li. An Overview of American Interstate Ecological Governance and the Enlightenment for China. International Journal of Environmental Protection and Policy. Vol. 7, No. 4, 2019, pp. 117-126. doi: 10.11648/j.ijepp.20190704.13

Received: July 6, 2019; Accepted: August 15, 2019; Published: September 2, 2019

\begin{abstract}
The existing US interstate ecological governance system can be divided into three categories according to the governance subject: traditional government governance, inter-governmental cooperation governance and special organizational governance. Traditional ecological governance is a government-led public governance, that is, the use of public power. US interstate eco-governance governance includes administrative control-led environmental regulation, legislative legislative ecological behavior, and judicial system environmental litigation ruling. Interstate issues are essentially intergovernmental relationships, so inter-governmental cooperation mechanisms are the proper meaning of interstate ecological governance. Traditional interstate agreements and central government cooperation governance are two common ways of interstate cooperation governance. The special organization is the Tennessee Valley Authority (TVA), which is a company based in the United States. It is a state-owned company that was established in May 1933 in accordance with the Tennessee Valley Authority Act. Formal operation, it is a regional comprehensive governance and comprehensive development plan, "is the first organized attempt in the history of the United States to skillfully arrange the fate of the entire basin and its residents." The US interstate ecological governance system is effective and relevant. The governance system that basically meets the requirements of multi-center governance plays an active role in dealing with interstate ecological environmental disputes and protection. China and the United States have certain similarities in the field of ecological governance. On the basis of national conditions, China's cross-regional ecological governance can learn from the US's governance experience to achieve "good governance" of cross-regional ecological problems.
\end{abstract}

Keywords: United States, Interstate Ecological Governance, Essential Attributes, Revelation

\section{Introduction}

The collaborative governance of interstate ecological affairs in the United States, a country with a vast territory and a federal system, has always been the federal government and states' concerned issues. Thus, they have explored a number of more effective governance ways and experience in practice. The existing US interstate ecological governance system can be divided into three categories by governance subject: traditional government governance (law-making, law enforcement, administration of justice), inter-governmental cooperation governance and special organizational governance. Subject to this, this article strives to take a more comprehensive consideration of interstate governance system in the United States and summarize the essence of this system's effective operation by reviewing the governance practices of different subjects.

\section{Method}

\subsection{Government Governance}

Traditional ecological governance is government-led public governance, that is, the regulation of applying public power. US interstate eco-governance includes the administrative power-led environmental regulation, the ecological legislative acts of legislative organs and the Department of Justice environmental litigation ruling. Maybe, someone would have different opinion, just as Brian Singleterry thought that there are currently four methods for resolving water disputes between states: litigation in the Supreme Court, congressional allocation, Interstate Compacts and the market method, 
however, markets operating between the states are either unconstitutional or insignifican [1]. We believe that the views of this study have been covered the Brian's opinion.

\subsubsection{Environmental Control}

Since the mid-19th century, the federal government has been the dominant force in the management of ecological resources, adhering to the principles of pragmatism and cooperation in dealing with the ecological problems between regions $[2,3]$.

The US federal government has two specialized environmental protection agencies: the Council on Environmental Quality (CEQ) and the Environmental Protection Agency (EPA). In addition, other relevant departments of the federal government also have corresponding environmental protection agencies.

The Regional Office of the Federal Environmental Protection Agency (EPA) is the primary administrative agency for coordinating interstate ecological affairs. For the sake of environmental supervision and management, the Federal Environmental Protection Agency divides 50 states into 10 regions and establishes regional environmental offices in each region. The Regional Environment Office conducts federal environmental laws on behalf of the Federal Environmental Protection Agency, implements federal EPA projects, and oversees environmental behavior in each state [4]. The state has its own environmental management agency and is not affiliated to the Federal Environmental Protection Agency, but is subject to supervision by the regional office. The State Environmental Protection Agency cannot cooperate with the Federal Environmental Protection Agency unless expressly provided by federal law. In addition, the Office of the Congress and the Office of Intergovernmental Relations (OCIR), as the primary contact point for Congress, state and local governments, also have some inter-regional ecological coordination functions [5].

The main bottleneck in the current federal interstate ecological governance is the difficulty in properly coordinating state sovereignty requirements, federal sectorial governance programs, and relationships among different constituencies. In other words, the good governance of interstate ecological affairs needs to coordinate the relationship of three dimensions: First, the dual sovereign state system makes the balance of interests between the federal and state, which needs to consume a lot of time and administrative resources; Second, the administrative authority of ecological governance is divided by multiple departments, and the interests of departments, departments and states and states are superimposed, thus making it difficult to reach collective consensus. Third, in representative countries, political election cycles, the impact of the division of constituencies on public policy are also very obvious. Different political parties and politicians have to first consider the impact of policies on elections when making public decisions. The overall nature of ecological governance is naturally"accepted" in the political landscape.

\subsubsection{Ecological Legislation}

The macro-level interstate ecological legislation is the national federal ecological legislation which mainly includes the Rivers and Harbors Acts, the Clean Water Act, the Endangered Species Act, the Coastal Zone Management Act, the Fish and Wildlife Coordination Act. These bills are the basic institutional norms and principles for conducting cross-state ecological governance.

Another aspect of ecological legislation is federal administrative legislation that address specific regional ecological issues. The federal Environmental Protection Agency (EPA), for example, to achieve legislative goals "Clean Air Act" promulgated the "regional haze regulations" (Regional Haze Rule) in 1999. The Regional Haze Management Regulations is governed by a nationwide 156 cross-regional area of atmospheric control, including national forest parks and wildlife sanctuaries. The bill controls atmospheric pollutants (including PM 2.5 and compounds that form PM 2.5), and aims to increase atmospheric visibility in 156 regions. At the same time, the regulations require state governments to develop phased air pollutant emission reduction targets and specific operational options [6]. Federal legislation is one of the more efficient means of resolving public ecological resource disputes and conflicts between regions. The central legislation can clarify the rights and obligations of different regional entities to their ecological resources and construct an effective ecological resource management mechanism to coordinate the contradiction between the regional interests and the public interests [7].

\subsubsection{Judicial Decision}

The judicial ruling of the Federal Court is considered by the academic community to be an important way to solve interstate ecological problems, and this is one of the manifestations of the American judicial tradition. Its main role is to explain relevant environmental laws, judicial decisions and judicial review of environmental disputes. The US federal judicial system consists of the Supreme Court, 11 federal appeals courts, and 90 federal district courts. The Supreme Court has jurisdiction over interstate disputes in accordance with Chapter III Section II, Article II of the Federal Constitution.

The value of the federal court system for interstate ecological governance is reflected not only in the implementation of the judicial decree to ensure the implementation of the ecological decree which is the legal support required to achieve the law but in the realization of multiple governance through civil environmental litigation as well.

Interstate rivers are subject to the doctrine of equitable apportionment, whereby the Supreme Court seeks to ensure that all states that share such rivers get a fair portion of their benefits [8]. The Court made clear that environmental harm is relevant in determining whether a state is receiving its equitable share of the waters of an interstate river, although all factors are relevant in an equitable apportionment determination [8]. The court will apply too strict a standard 
when he determined that the Court would not be able to fashion an appropriate equitable decree [8].

A typical case of promoting interstate ecological law enforcement through judicial decisions is the Supreme Court's ruling on National Ambient Air Quality Standards (NAAQS). In 1997, the Federal Environmental Protection Agency developed new "Main National Air Quality Standards" and "Secondary National Air Quality Standards" in accordance with the Clean Air Act, which gave rise to opposition from some states and industries and a large number of lawsuits requiring the court to confirm that the EPA does not have the authority to change the national air emission standards set by Congress, and that the new national air quality standards are unconstitutional. On February 7, 2001, the US Supreme Court issued a final judgment against the Whitmanv, American Trucking Associations, arguing that under Section $109 \mathrm{~b}$ of the Clean Air Act, major national air quality standards can be corrected (first) and the secondary national air quality standards can be amended (second) in order to protect public health and citizens' rights; -therefore, the EPA's act to improve the national air standard is constitutional [9]. The EPA has obtained judicial support for the implementation of air emission standards through judicial decisions, and States and various industry sectors are not allowed to impede air quality improvement due to their respective economic conditions or technical level. Therefore, Davidson and Norbeck believe that the federal court's judicial decision is a key factor in the EPA's efforts to implement the Clean Air Act [10]. Although the judicial ruling is critical to the implementation of the Federal Ecological Act, by analyzing the water distribution and economic and social development of the different regions of the Delaware River Basin in New Jersey v. New York, Mandarano points out that the judgment made by the Federal Supreme Court judgment is relatively static and appears to be incapable of responding to the changing ecological governance situation [11].

In June 2015, the United States Supreme Court granted the State of Mississippi leave to file a bill of complaint against the State of Tennessee, the City of Memphis, and Memphis Light, Gas \& Water Division for wrongfully converting groundwater from the interstate Sparta-Memphis Aquifer. From this case, a new judicial principle in the interstate water conflict, a third alternative, the Supreme Court's doctrine of interstate nuisance, which recognizes and balances competing sovereign interests in utilization and preservation of shared interstate natural resources [12].

Another important value of justice in interstate ecological governance is to protect citizens' environmental litigation and promote the realization of multiple governance. Citizen participation is an important feature of contemporary ecological governance and a major factor different from traditional environmental regulation. However, when faced with a powerful public authority, the individual's power always appears relatively small. Through judicial proceedings, citizens can use the constitutional design of the three powers to effectively influence the formation and implementation of public ecological policies. The case of Hill v. Tennessee
Valley Authority v. Hill is a typical example. In 1978, two environmental organizations in Tennessee, led by Hill et al., and some citizens filed a civil lawsuit in the Federal District Court with TVA as the defendant. They believed that TVA violated the provisions of The Endangered Species Act and asked the court to confirm it. Violation of the law and the termination of the construction of the Tailiku Dam, a key habitat for the snail dart [the endangered squid of the Tennessee River often referred to as the Snail Darter]. The final judgment of the Supreme Court supported the appeal of Hill et al. with a $6: 3$ advantage $[13,14]$.

\subsection{Inter-governmental Cooperation Mechanism}

Interstate issues are a matter of essentially intergovernmental relationship, so inter-governmental cooperation mechanisms are the proper meaning of interstate ecological governance. Traditional interstate agreements and central government cooperation governance are two common ways of interstate cooperation governance.

\subsubsection{Interstate Agreement}

"There is no doubt that the founders and designers of the US Constitution want states to resolve interstate disputes through interstate agreements [15]. According to the earliest federal constitution, the state is not capable of handling complex interstate disputes. Therefore, on the premise of meeting the requirements of Congress (Article 3 of Section 10 of the US Constitution), the Constitution grants each state the permanent use of the Interstate Agreement (in the colonial period it was widely used to resolve border disputes and was recognized by the federal declaration) to resolve interstate disputes.

The Clean Air Act also relies on interstate agreements to achieve interstate air co-management. According to 102 (a) Provisions, by establishing interstate contracts or interstate agreements, interstate cooperation is encouraged on air pollution and prevention. 102 (c) states that, without prejudice to federal decrees or treaties, Congress recognizes state-state air governance contracts or agreements between states and states [16].

Moreover, in the current practice of governance in the United States, the Supreme Court, which has a final ruling on interstate disputes, prefers states to use interstate agreements to replace litigation [17] or interstate agreements as much as possible before litigation. In 1991, the Federal Supreme Court called on the parties to resolve their disputes through multiple dialogues and agreements in the judgment of Oklahoma and Texas v. New Mexico [11].

Interstate agreements are superior to judicial decisions in three aspects: First, the implementation rate of interstate agreements is high. Interstate agreements are the product of extensive consultations between states and have reached a consensus on action. Interstate agreements are "autonomous actions" compared to the enforcement of judicial decisions made by the courts, and efficiency and cost are often superior to "passive actions" that rely on judicial coercion. Second, interstate agreements can adapt to the needs of economic development more quickly. Judicial decisions are usually a 
"quiet" evaluation of a particular situation, and the making of such an evaluation usually takes a large time cost - the judicial decision is bound to be later than the dispute, so the judicial ruling of the past judgment cannot and should not be based on the current economic and social development. The governance of the Delaware Basin is an example. New Jersey v. New York judged that although the water distribution in Delaware (DRB) basins was decided, the ruling could not adapt to economic development and cause the development dilemma of the watershed states. The Delaware Basin Commission (DRBC) was formed to resolve this problem through an interstate agreement between the federal and relevant states. Third, the scope of adjustments to interstate agreements is less restrictive. Mandarano studied 38 interstate agreements involving the US fisheries and wildlife sectors, including adjustments in water resources allocation, pollution control, flood protection, and water management [18]. McCormick pointed out in more detail that the western states have signed more interstate agreements than those in the eastern region, and the areas of concern are different: the west is mainly concentrated on water resources, while the east is mainly on water quality and flood control [19]. Additionally, integrated river basin management has been widely advocated in the United States, as a good governance of rivers [20].

The interstate agreements are generally implemented in three ways. The first is to set up a permanent office. Committees are usually set up to enforce interstate agreements but the implementation of the East and West is different. The power of the interstate agreement enforcement agencies in the west is relatively small, as the western states are not accustomed to granting resource management rights to third parties. Kenney believes that a well-established inter-regional agreement committee should include a federal representative, the governor of the contracting state, or its representative, and should highlight the status of the federal representative or federal adviser: the states must agree with the non-voting federal representative when voting on important matters [21]. While lacking coercive power to compel enforcement, most interstate compacts create accountability through multiple sources and layers connecting enforcement behavior to oversight (Luke Fowler, Isaac Castellano). Creating Accountability with Interstate Cooperation: Unauthorized Water Use Enforcement on the Klamath River Second, the justice is forced. Litigation is an important means of forcing states to fulfill their agreements. This approach is more prominent in the West. The implementation of interstate agreements between New Mexico and Texas on the Pecos River, Colorado, Nebraska and Kansas on the Republican River is dependent on the judicial decision of the federal court. Third, resource use regulations are established. Western interstate agreements usually set up regulations to control water volume and flow to coordinate water use between upstream and downstream. At present, the obstacles to the implementation of interstate agreements are first of all that interstate agreements tend to focus only on the allocation of resources, while ignoring the ecological quality control of resources and habitat environmental protection. Second, cooperation agreements that require agreement often result in inefficient decisions that ultimately enable interstate agreements to function only as information gathering and federal government communications intermediaries in the basin's states. Finally, many interstate agreements are made early so that they are difficult to cope with the current governance situation and are not consistent with federal ecological governance programs and programs - it is difficult to integrate federal departments and policies into the framework of interregional agreements: The federation is not a formal party to an interstate agreement, even if the agreement is passed, parliamentary approval can bind the federal department and grant it no voting rights, but the parliament retains the power to pass the opposite law or change the rules of the agreement.

\subsubsection{Central Cooperation}

Centralized cooperative governance is a new initiative of the federal government on interregional ecological issues. Typical representatives are the River Basin Commission established under the Water Resources Planning Act of 1965 (WRPA) and the National River Estuary Program of the Federal-State Cooperative Governance Model established under the Clean Water Act Amendment Act.

The jurisdiction of the domain committee includes water resources and related land resources. The powers include coordinating federal, state, and state water resources development plans for local governments in the state, preparing and updating relatively comprehensive cooperation plans, requiring parties to provide Relevant data, but the Congress restricts the watershed committee from direct adjustment and management of water resources, which makes it difficult for the river basin committee to formulate effective regional planning and lack direct resource management authority, thus leading to the "short-lived and inefficient" river basin committee.

The National Estuary Program is federal-state cooperative governance that is initiated by the federal government and participated by relevant states. This type of cooperative governance is currently more common because it is easier to be established and maintained, and the parties can benefit while retaining their own jurisdiction. The federal support for partnerships is clearly defined by law, and states are usually bound by the memorandum of understanding reached and the action resolutions of the participating agencies. Mandarano's study of the implementation of the National Estuary Program considers that the federal-state cooperative governance approach is fruitful and fosters innovative inter-state problem-solving mechanisms and technical capabilities. However, this is a kind of cooperation rather than specific project governance and the federal-state cooperative governance is often plagued by lack of funds and limited personnel, so that it is difficult to work independently. Just like other central and local cooperation, it also faces coordination. And it is difficult to implement [22]. Sherk provided a solution to this problem, stating that if federal-state cooperation is to achieve greater results, special decrees must be enacted 
through Congress to coordinate the management of interstate ecological resources [11].

\subsection{Special Organizational Governance}

Water markets are a prime example of decentralized resource allocation, yet their success often depends on strong coordination institutions, particularly as water is redistributed across sectors and political borders. A study comparing coordination institutions in Australia, Spain and the Western USA showed that all three countries have required capable coordination institutions to address the distributional conflicts associated with water markets. Coordination institutions can take multiple forms and include both formal and informal venues for planning, financing and conflict management matched to local conditions [23].

The Tennessee Valley Authority (TVA) is an American interstate water management agency established in May 1933 in accordance with the Tennessee Valley Authority Act, operating as a state-owned company. It is located in Knoxville, Tennessee, and its scope of action is in the Tennessee Valley, which is 40,000 square miles in seven states of Tennessee, Virginia, North Carolina, Georgia, Alabama, Kentucky, and Pennsylvania. It is a regional comprehensive governance and comprehensive development planning which is"the first organized attempt in the history of the United States to skillfully arrange the fate of the entire basin and its inhabitants" [24].

TVA has made great achievements in the restoration and governance of the Tennessee Valley. This is mainly due to TVA's "ruling by law" - the Tennessee River Sector Administration Act clearly defines its functions, tasks, and powers: TVA is a relatively independent government agency which functions only under presidential leadership and congressional supervision. It also has extensive autonomy in watershed development management and assumes all the functions of domain planning and management, so that it can report directly to the President and Congress by crossing the general procedures. It can avoid the inefficiencies in governance resulting from conflicting interests between federal departments and between states [25]. As a special governance institution, TVA reflects the basic concept of interstate ecological governance in the United States multi-center governance: governance means a series of social public institutions and actors from the government but is not limited to the government; governance means there are ambiguities in boundaries and responsibilities in the search for solutions to social and economic problems; governance clearly affirms that there is power dependence between various public institutions involved in collective behavior; governance means that participants will eventually form an autonomous networks; governance means that the ability to do good things is not limited to government power, not limited to government orders or the use of authority [26]. Specifically, TVA as a national river basin management institution embodies the government's governance of ecology. The operation of state-owned companies reflects the value of market governance for ecological problems. The operating system focuses on community organizations and citizen participation guarantees the participation of social forces in ecological affairs.

\subsection{Market Governance}

In the 1950s and 1960s, the mainstream economics in the United States regarded environmental pollution as an inevitable result of "market failure." Under the influence of this academic thought, the US government naturally excludes the market from the main body of governance when conducting ecological governance. According to the mainstream view, the market is unable to play the role of optimal allocation of resources in environmental governance. For example, the price mechanism cannot market the negative problems such as water pollution, air pollution and noise pollution, so it is impossible to form negative aspects such as water pollution. From the perspective of transaction economics, the private cost of mainstream economists at that time was less than the cost of recovery, and the social cost of governance was less than private cost. Therefore, enterprises will inevitably be more polluted and less governed, and it is impossible for price mechanism to realize optimal allocation of resources in ecological governance Therefore, the government becomes the main body of ecological governance. The market mechanism cannot impose appropriate restrictions on polluters. Manufacturers will not voluntarily reduce the emission of toxic chemicals, nor will they change the toxic waste into the dump. Pollution control has always been regarded as the legitimate function of the government. In addition, mainstream economics believes that environmental pollution is external and cannot be governed by clear property rights, so it cannot rely on the market for ecological governance. This understanding is not reversed until Alen V. Kneese's "Environmental Emission Pricing Theory" and Coase's "social cost theory" is put forward respectively. Since then, the US government has begun to pay attention to the use of market methods for ecological governance, adhere to the decisive position of market mechanisms in environmental governance, and concentrate on emissions trading in interstate ecological governance. The allocation, use and trade of water rights in river basins can be realized through market behavior.

The public-private partnership in the Colorado River Basin is a typical example of the introduction of interstate ecological governance into the market. The Colorado River has a length of about $2,333 \mathrm{~km}$ and a drainage area of $637,000 \mathrm{~km}^{2}$. The main river flows through 7 states --- Wyoming, Division Rado, Utah, New Mexico, Nevada, Arizona, and California. This river is known as the "lifeline of the Southwest," a typical interstate river. In the mid to late 20th century, the economies of the basins ushered in a rapid development. During the period, the originally limited flow was difficult to meet the water demand of the seven states. The contradiction between supply and demand was tight. The original Interstate Agreement such as the Colorado River Agreement could not allocate resources quickly and effectively, and the administrative system on which interstate agreements depended also presented the predicament of "governance 
failure" in the ecological governance basin. The emergence of market-based solutions has become a necessity. In the late 1990s, the Federal Ministry of Internal Affairs promulgated the Colorado River Rules, which clarified the water rights of the states. Later a special organization for the coordination of marketization and administrative governance was established. In this way, all stakeholders in the river basin are involved in governance and effective transfer of water rights between states is successfully made. The most interesting water rights transactions in the Colorado River Basin Trading are California's purchase of 1.6 million acres per foot of Imperial Irrigation in 2002 which was sold to the southern part of the state at a higher price [27].

Through the intervention of the market mechanism, the US interstate ecological administrative governance mechanism has achieved a high degree of integration with the social market economy. On the one hand it effectively makes up for many deficiencies and shortcomings of administrative mechanism in inter-state ecological management watershed, reduces the administrative cost and improves the efficiency of governance. On the other hand, the enthusiasm and initiative of the market entities are fully explored, the resources are optimally allocated according to the laws of the market, and the goal of "good governance" of interstate ecological problems by means of market competition and cooperation is achieved.

There is a newly-presented market method to resolve the disagreement for interstates water resources, an interstate water bank program among the Colorado River Basin. There are three main shortfalls to this though, which do not make the program a viable approach in addressing the problem: (1) legal uncertainty regarding individual water rights; (2) concerns regarding speculation; and (3) lack of incentives for state participation. Compact compliance may be a better use to settle those barriers. Compact provides legal certainty regarding individual water rights, which in turn encourages participation of depositors in the water bank program. Finally, compact compliance as a beneficial use incentivizes states to negotiate and contract to an interstate water bank agreement because it decreases the transaction costs associated with such a program [28].

\section{US Interstate Ecological Governance Experience}

The US interstate ecological governance system is an effective governance system that meets the basic requirements of multi-center governance and plays an active role in dealing with interstate ecological environmental disputes and protection. The reason why the governance system can be operated in an orderly manner can be seen from its three essential attributes.

\subsection{US Interstate Ecological Governance Is a Comprehensive Governance}

First of all, it is reflected in the multi-pronged and synergistic effect of legislative power, judicial power and administrative power. Ecological governance is a systematic project, which requires different state power organs to give full play to their functions in social affairs management. Each of them has the responsibility and cooperation to form a joint force of governance. The legislature provides a good and sufficient supply of ecological systems. Law enforcement agencies actively ensure that ecological laws and regulations are effectively operated in reality, and the judiciary provides necessary judicial support for the implementation of laws and regulations and, to a certain extent, amends and creates new ecological laws. Abandoning the legislative worship and administrative centralism of ecological governance, the government's public authority plays a synergistic role, fulfilling the state's public service functions, and promoting the realization of the "good governance" of interstate ecological problems.

Secondly, it is reflected in the combination of traditional state governance and inter-governmental cooperation governance. Traditional public affairs management implementation bodies are nothing more than legislative, administrative, and judicial institutions, mainly administrative agencies, and can deal with social affairs before the industrial era. However, in the post-industrial era, the traditional government's public management model has frequently faced "governance failure" in the face of its extremely complicated interstate ecological affairs. Therefore, new governance methods have emerged in practice-inter-governmental cooperation governance. Inter-governmental cooperation governance includes state-to-state consultation and cooperation, as well as central government cooperation between the federal government and the state. Inter-governmental cooperation governance is more flexible and convenient than traditional state governance. It can focus more on the negotiation and cooperation of governance entities. Through the interests of different subjects, it is possible to fully agree on the collective action consensus, so its governance effect is more effective. The US interstate ecological governance not only ensures that the traditional and inter-governmental cooperation governance methods play their respective roles, but also realizes the comprehensive management of the two.

\subsection{US Interstate Ecological Governance Is the Governance of the System}

The constitutional construction ensures the formation of rational government, mature market, and developed society required for public governance, actively promotes the existing public governance reform and new public governance mechanisms, cultural growth and prosperity. In the governance, the market and social subjects can fully express their opinions, participate in decision-making on an equal footing, and effectively supervise their implementation. It is worth noting that the extension of the rule of law in the context of public governance has evolved - not only the traditional "hard law" governance, but also the "soft law" governance that cannot be enforced by state enforcement. Since the "soft 
law" is generated through cooperation and negotiation between regions, its governance effect is sometimes superior to the "hard law" - "soft law" plays an important role in regional cooperation governance. Therefore, the institutional governance of interstate ecological governance in the United States includes both traditional statutes and jurisprudence of jurisprudence, as well as states that are widely recognized and play an important role in federal constitutions and judicial precedents agreement.

\subsection{US Interstate Ecological Governance Is Diversified Governance}

Multi-governance means the effective participation of governments, markets and civil society in public governance. Government governance is no longer the only model of public governance. Marketization and civil society participation governance are both indispensable parts of public governance, so as to change a series of problems such as simplicity, loss of efficiency, rent-seeking corruption in the provision of public goods. American interstate ecological governance includes different governance methods of government, market and society. For the time being, the traditional governance is not to be overlooked. Market-oriented governance is mainly reflected in the outstanding corporate operation management of the Tennessee Valley Authority (TVA), while citizen governance is reflected in the participation of citizens represented by public welfare environmental litigation. Any kind of governance has its inherent flaws; it is difficult to deal with complex and changing interstate ecological affairs, and organic integration of three different ways in ecological governance can improve governance efficiency and better control and guide public affairs.

\section{Enlightenment of American Interstate Ecological Governance to China's Interregional Ecological Governance}

China and the United States have similarities in cross-regional ecological governance: in terms of land area, they belong to a vast country with a vast territory, and the local authorities have corresponding autonomy. China is in the stage of experiencing frequent environmental crises caused by the industrialization that the United States has experienced. Therefore, China's cross-regional ecological governance should be based on the national conditions and we should actively draw lessons from the experiences of foreign countries in regional ecological governance, and realize the sustainable development of the national economy, while exploring the ecological governance road that suits itself.

There are two enlightenments of interstate ecological governance in America on the "good governance" of cross-regional ecology in China: at the macro level, it is enlightened that China's cross-regional ecological governance should realize the unification of traditional environmental regulation and inter-governmental cooperation governance. The enlightenment to China's cross-regional ecological governance includes standardizing the formulation and implementation of regional administrative agreements, improving market participation in governance, focusing on the role of justice in the regulation of cross-regional ecological governance, and innovating cross-regional ecological governance organizations.

\subsection{Realizing the Unification of Traditional Environmental Regulation and Inter-governmental Cooperation Governance}

The dilemma of cross-regional ecological governance in China is related to the existing environmental management system. The establishment of ecological management institutions in China implements the system of separate management of environmental protection and ecological recourses management, resulting in the overall ecological governance separated by specialized administrative agencies. In addition, China's current environmental management basically belongs to the "administrative area ecology": Ecological governance is divided by administrative divisions, and local governments are only responsible for the ecological environment of their respective jurisdictions. This kind of "sectorial division" and "regional closure" environmental management system is obviously difficult to meet the requirements of regional ecological synergy development.

Inter-governmental governance means that the collective governance consensus is finally reached, and then the cooperation and coordinated governance of public affairs can be realized under the existing system, through the full consultation and game between different governments and departments. Inter-governmental governance is based on the action consensus among all parties whose interests are optimized, so participants have higher enthusiasm for action, and the purpose of governance is easier to achieve. Moreover, it is difficult for traditional national governance systems to specifically regulate the emerging cross-regional ecological problems. It takes a lot of manpower, material resources, financial resources, and high time cost for ecological administration, ecological legislation, and judicial decisions while the result of governance is often not satisfactory. Interstate ecological governance in the United States relies more on interstate cooperation to bridge the gaps in traditional governance, including state-to-state cooperation, and cooperation between federal and state governments.

Based on the existing national governance system and drawing on the experience of the US interstate ecological governance system, China should carry out extensive intergovernmental ecological cooperation governance in order to realize the coordinated development of regional ecology. Besides China should combine environmental control with inter-governmental cooperation and governance, deepen the reform of the administrative system, integrate the main body of ecological law enforcement, relatively centralize the power of law enforcement and promote comprehensive law enforcement. Efforts should be made to solve the problems of overlapping powers and responsibilities and multi-pronged law enforcement and to establish the unity of powers and 
responsibilities. A unified, authoritative and efficient ecological administrative law enforcement system should be established. In the meantime, we should actively promote, encourage and guarantee the development of normative ecological cooperative governance among local governments.

\subsection{Standardizing the Formulation and Implementation of Regional Administrative Agreements}

The district-level administrative agreement is the textual embodiment and implementation norm of inter-governmental cooperation. Since the main way of cross-regional ecological governance is inter-governmental cooperation, the institutionalized regional administrative agreement becomes the institutional support for cross-regional ecological governance. The United States is extremely encouraged and respected for interstate ecological governance. In the Constitution and other ecological single-line laws, it is explicitly proposed to encourage local governments to adopt administrative agreements for ecological governance, and to have clear regulations on the formulation, implementation, and responsibility of interstate agreements.

Areas under heavy pressures from ecological and environmental management in China also have regional administrative agreements, such as the Pan-Pearl River Delta Regional Environmental Protection Cooperation Agreement and the Pan-Pearl River Delta Regional Cross-border Environment, Administrative Measures for Pollution Disputes, "Pan-Pearl River Delta Regional Environmental Protection Industry Cooperation Agreement", "Beijing-Tianjin-Hebei Metropolitan Area Regional Planning Environmental Protection and Ecological Construction Special Plan", "Yangtze River Delta Environmental Protection Cooperation Agreement", etc. which are mainly implemented in the Pearl River Delta, Yangtze River Delta and Beijing-Tianjin-Hebei regions. However, these inter-regional administrative agreements are only a kind of spontaneous exploration and attempt by the inter-regional government on environmental pressure. The nature of the agreement, the definition of responsibility and the resolution mechanism of administrative agreement disputes lack clear laws and even legal principles. There is currently no corresponding legal basis for the administrative agreement, which makes the agreement face the dilemma of legal application. Therefore, in the future, laws and regulations should be amended to make certain standards for the legal nature of inter-regional administrative agreements, dispute resolution, and liability for breach of contract so as to truly play its positive role in cross-regional ecological governance.

\subsection{Ensuring Participatory Governance of the Market}

One of the characteristics of interstate ecological governance in the United States is the participation of market and social forces to achieve multiple participation in governance. The market can promote the optimal allocation of ecological resources between different regions and improve the efficiency of resource use.
In terms of market participation governance, the paradigm of cross-regional governance in the United States -the Tennessee Field Administration (TVA) is a company-based operation management. According to the management of the state-owned company's ecological resources in the Tennessee River Basin, it realizes both the organic unity of ecological protection, resource development and utilization, and comprehensive management of the basin.

The Third Plenary Session of the 18th Central Committee is based on the effectiveness of the market in domestic ecological governance practices, and proposes to establish an environmental marketization mechanism between regions and promote Cross-regional market governance. China's cross-regional market governance currently consists of three main aspects: First, under the principle of the main functional area planning, the ecological compensation mechanism for key ecological functional areas should be improved and the establishment of a horizontal ecological compensation system between the regions should be promoted; Besides, we should develop environmental protection markets, implement carbon emission rights, emission rights, and water rights trading systems between regions and regions; we should also establish a market-based mechanism to attract social capital into ecological environmental protection and promote third-party environmental pollution management.

\subsection{Focus on the Regulating Role of Justice in Cross-regional Ecological Governance}

Judicature is often referred to as the "regulator" and "safety valve" of social contradictions. The role of justice in cross-regional ecological governance mainly refers to the settlement of ecological interest disputes between the central and local, local and local through judicial decisions.

Judicature plays an important role in the interstate ecological governance of the United States. On the one hand, judicial decisions are used to promote the implementation of ecological laws, to establish new ecological case law and to revise the ecological law gradually in judicial practice. On the other hand, it is to ensure that the interstate agreements are actually implemented.

Although China does not implement the case law system and the "constitutional review system", there are case guiding principles of the Supreme People's Court, which can be regarded as a "quasi-judgment law". Through administrative, civil and criminal litigation involving cross-regional ecological governance, relying on judicial procedures to resolve disputes in regional ecological governance practices, judicial judges will have a clear expectation in the national cross-regional ecological governance practice, and play a guiding role in the law, forecasting and evaluation functions.

\subsection{Innovative Interregional Ecological Governance Organization}

The successful experience of the Tennessee Sector Authority indicates that cross-regional ecological governance cannot be rigidly adhered to the traditional single-state 
bureaucracy, nor should it be confined to a single market and social organization. We should be brave in institutional innovation, bring government governance, market governance and social governance mechanisms. Unified application, innovative governance organization model and the corporatization operation help to achieve optimal allocation of inter-domain ecological resources. The social governance mechanism can ensure the democratic and scientific nature of public governance, while the administrative organization attributes can help improve governance efficiency and coordinate the interests between the central and local governments.

As far as China's cross-regional governance practices are concerned, regional ecological governance organizations are mainly joint meetings of the central ministries and commissions and loose regional governments. The central ministries and commissions are mainly the regional inspector's center of the Ministry of Environmental Protection and the Dajiang River Committee of the Ministry of Water Resources. They are all administrative units, and their functions are only an extension of some regulatory departments of the dispatched institutions. In the practice of cross-regional governance in China, the time is relatively short and its scale is small, normative and synergistic. The influence of civil institutions in China's ecological governance is mainly the environmental protection propaganda and public opinion supervision of environmental protection organizations, which have not been effectively formed in regional ecological governance. It can be seen that China's current cross-regional ecological governance organization is not systematic, and effective regional ecological governance organizations are currently in a state of "absence", not to mention organizational innovation. Therefore, in the future regional ecological governance in China, we must pay attention to the cultivation and development of governance organizations, emancipate the mind, get rid of the shackles of organizational attributes, and base on the actual conditions, innovate the organizational model of regional ecological governance according to local conditions.

\section{Conclusion}

Inter-regional ecological co-governance is a public governance problem, especially for large countries with vast territory. At present, no major country has achieved good governance of ecological affairs between regions, and there are only countries which have carried out different explorations. Studying the inter-regional ecological governance system in the United States does not mean that the United States has fully realized the synergy and co-governance of inter-regional ecological affairs, and thus there is no intention to transplant its governance system into China. Just because of the consideration of "the stone of other mountains, you can attack jade", with reference to the comprehensive management of the interstate ecology of the United States, the governance of the system and the practical experience of multi-dimensional governance, we will innovate
China's regional ecological governance methods and improve the level of ecological governance. In particular, it is necessary to learn from the successful experience of the "institutional governance" of the interstate ecology of the United States. In the new historical journey of building China's socialist ecological civilization and realizing the coordinated development of regional ecological civilization, it is necessary to establish a systematic and complete system of ecological civilization. Reform the ecological environmental protection management system and protect the ecological environment with the system.

\section{Acknowledgements}

Fund projects: Major Special Topics of the National Social Science Foundation: Xi Jinping's Research on Socialist Ecological Civilization (18VSJ006). Phased Achievements of the 65th Batch of the China Postdoctoral Science Foundation: Study on Xi Jinping's View of Ecological Rule of Law in the New Era (Project No. 2019M650942).

\section{References}

[1] Brian Singleterry, Marketing Interstate Harmony: Interstate Water Markets as an Alternative to Resolving Water Conflicts, 2 Tex. A\&M L. Rev. 527, 2015.

[2] WONDOLLECK J M, YAFFEE S L. Making Collaboration Work: Lessons From Innovation in Natural Resource Management [M]. Washington, D. C.: Island Press, 2000.

[3] SCHEBERLE D. Federalism and Environmental Policy: Trust and the Politics of Implementation [M]. Mishawaka, IN: Georgetown University Press, 2004.

[4] About EPA [EB/OL]

http://www.epa.gov/aboutepa\#pane-4.

[2013-09-21].

[5] About the office of congressional and intergovernmental relations (OCIR) [EB/OL]. [2013-09-21]. https://www.epa.gov/aboutepa/about-office-congressional-and -intergovernmental-relations-ocir.

[6] Regional HazeRule [EB/OL]. [2013-12-26]. http://www.epa.gov/ttn/caaa/t1/frnotices/rhfedreg.pdf.

[7] DELLAPENNA J. Transboundary water sharing and the need for public management $[\mathrm{J}]$. Journal of Water Resources Planning and Management, 2007, 133 (5): 397-404.

[8] Reed D. Benson, Can a State's Water Rights Be Damned? Environmental Flows and Federal Dams in the Supreme Court. Michigan Journal of Environmental and Administrative Law, Vol. $8 \&$ 371, 2019. Florida v. Georgia, 138 S. Ct. 2502, 2516 (2018).

[9] Whitman v. American Trucking Associations. Supreme Court Decision on the EPA's Ozone \& Particulate Matter Air Quality Standards [EB/OL]. EPA. (2001-02-27) [2013-10-17]. http://www.epa.gov/ttn/naaqs/standards/ozone/data/2001_cour t_summary.pdf.

[10] DAVIDSON J. Federal leadership in clean air act implementation: the role of the environmental protection agency [M]/DAVIDSON J, NORBECK J M, eds. An Interactive History of the Clean Air Act. Oxford: Elsevier, 2012: 19-40. 
[11] SHERK G W. The management of interstate water conflicts in the twenty-first century: is it time to call uncle? [J]. New York University's Environmental Law Journal, 2005, 12 (3): 764-827.

[12] Hall N D, Regalia J. Interstate Groundwater Law Revisited: Mississippi v. Tennessee [J]. Social Science Electronic Publishing, 2016.

[13] MURCHISON K M. The Snail Darter Case: TVA Versus the Endangered Species Act [M]. Kansas: University Press of Kansas, 2007.

[14] Tennessee Valley Auth. v. Hill 437 U.S. 153 (1978) [EB/OL]. [2013-10-17]. http://supreme.justia.com/cases/federal/us/437/153/case.html.

[15] SHERK G W. Dividing the Waters: The Resolution of Interstate Water Conflicts in the United States [M]. Hague Nethetand: Martinus Nijhoff Publishers, 2000: 29-30.

[16] The Clean Air Act [EB/OL] [2013-12-25]. http://www.epw.senate.gov/envlaws/cleanair.pdf.

[17] HUTCHINS W A. Water Rights Laws in the Nineteen Western States $[\mathrm{M}]$. Washington, DC: The Lawbook Exchange, Ltd., 2004: 66 .

[18] MANDARANO L A, FEATHERSTONE J P, PAULSEN K. Institutions for interstate water resources management [J]. JAWRA Journal of the American Water Resources Association, 2008, 44 (1): 136-147.

[19] MCCORMICK Z L. Interstate water allocation compacts in the western united states-some suggestions [J]. JAWRA Journal of the American Water Resources Association, 1994, 30 (3): 385-395.

[20] Cathy Suykens, 'Critical Success Factors in Transboundary Water Management: a US-EU Comparison' (2018) 27 European Energy and Environmental Law Review, Issue 1, pp. $2-14$.

[21] KENNEY D S. Institutional options for the Colorado River [J]. JAWRA Journal of the American Water Resources Association, 1995, 31 (5): 837-850.

[22] MANDARANO L A. Protecting habitats: New York-new jersey harbor estuary program collaborative planning and scientific information [D]. Philadelphia, Pennsylvania: University of Pennsylvania, 2004.
[23] Garrick, D. E., Hernández-Mora, N. \& O’Donnell, E. Reg Environ Change (2018) 18: 1593.

[24] EKBLADH D. "Mr. TVA": Grass-roots development, David Lilienthal, and the rise and fall of the Tennessee valley authority as a symbol for U.S. overseas development, 1933-1973 [J]. Diplomatic History, 2002, 26 (3): 335-374.

[25] About TVA [EB/OL]. http://www.tva.com/abouttva/ index.htm.

[2013-09-23].

[26] STOKER G. Governance as theory: five propositions [J]. International Social Science Journal, 1998, 50 (155): 17-28.

[27] WEISS E B, DE CHAZOURNES L B, BERNASCONI-OSTERWALDER N. Fresh Water and International Economic Law [M]. Oxford: Oxford University Press, 2005: 35-59.

[28] Halvorsen, Emily. Compact compliance as a beneficial use: increasing the viability of an interstate water bank program in the Colorado River Basin [J]. University of Colorado Law Review. Summer2018, Vol. 89 Issue 3, p937-966.

\section{Biography}

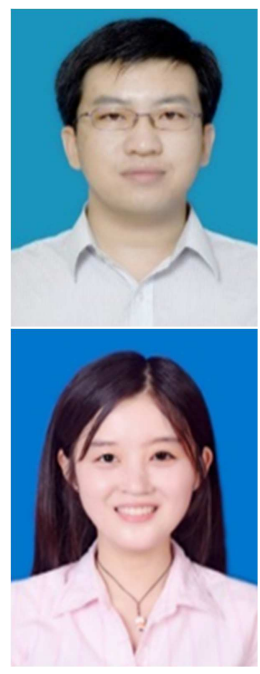

Guo Yongyuan (1986-), Associate Professor of Department of Administration, School of Public Administration, Shanxi University of Finance and Economics; Doctor of Law; Postdoctoral Researcher of Renmin University of China; Master Tutor.

Xiao Li (1990-), Postgraduate of the school of Ideological and political research, Shanxi University of Finance and Economics. 